\title{
MENGENAL KEPROFESIONALAN GURU
}

\author{
Siti Raihanah \\ Email: sitiraihanah020@gmail.com \\ Program Studi Pendidikan Sejarah Fakultas Keguruan dan Ilmu Pendidikan \\ Universitas Lambung Mangkurat \\ Banjarmasin
}

\begin{abstract}
Abstrak
Profesi guru adalah profesi yang tidak banyak menuntut persyaratan seperti profesi lainnya. Guru itu sebagai tenaga yang profesional berfungsi meningkatkan mutu dan kualitas pendidikan nasional. Guru sangat mempengaruhi terciptanya proses dan hasil pendidikan yang berkualitas.
\end{abstract}

\section{PENDAHULUAN}

Guru merupakan peran terpenting peradapan pendidikan di Indonesia maupun di dunia. Guru yang mengupayakan perencanaan dan melaksanakan proses pembelajaran dikelas, menilai serta membimbing peserta didik untuk menggapai impiannya. Profesi keguruan merupakan profesi yang akan menentukan masa depan anak bangsa. Tanpa adanya seorang guru apa jadinya negeri ini dan guru tanpa bahan pembelajaran, strategi pembelajaran, mendorong siswa belajar untuk mencapai prestasi yang tinggi maka, segala upaya peningkatan kualitas pendidikan tidak akan tercapai. (Susanto, 2020: 12)

Guru sosok teladan dan bahkan menjadi tokoh indentifikasi diri. Maka seorang guru itu diharuskan memiliki sifat yang dapat ditiru oleh peserta didik dan memiliki perilaku yang memadai untuk mengembangkan peserta didik secara utuh. Dalam upaya untuk menguasai kemampuan pembelajaran, guru perlu membina diri secara baik karena fungsi guru itu sendiri adalah pembina dan mengembangakan kemampuan siswa dan dirinya sebagai guru yang profesional sehingga siswa mendapatkan pengalaman belajar secara efektif dan efesien.

Kenyataannya tidak semua orang yang memahami betul apakah profesi. Orang menganggap bahwa profesi itu disamakan dengan pekerjaan pada umumnya. Kekeliruan itu sudah berlangsung lama dikalangan masyarakat masih banyak salah menganggap.

Profesi dapat diartikan sebagai suatu pekerjaan atau jabatan yang menuntut keahlian, dapat melalui pendidikan yang sudah digapai diperguruan tinggi maupun pelatihan tertentu, menurut persyaratan khusus memiliki tanggung jawab dan kode etik 
tertentu yang dicantumkan didalam undang-undang atau aturan yang telah dibuat agar seorang guru tetap dengan norma yang berlaku. Pekerjaan yang bersifat profesioanal berbeda dengan pekerjaan lainnya karena suatu profesi memerlukan kemampuan dan keahlian khusus dalam melaksanakan profesinya. Profesi dapat diartikan sebagai jabatan atau pekerjaan tertentu yang harus memiliki pengetahuan dan keterampilan khusus dalam mengajar yang diperoleh diperguruan tinggi atau akademis yang intensif. Artinya suatu jabatan yang berprofesi itu tidak dapat dipegang oleh sembarangan orang, tetapi memerlukan persiapan melalui pendidikan dan pelatihan secara khusus.

(Susanto, 2020: 13)

Guru merupakan pendidikan profesioanal dengan tujuan utama adalah mendidik , mengajar, membimbing, mengarahkan, melatih, menilai, dan mengevaluasi peserta didik pada pendidikan anak usia dini melalui pendidikan formal. Menurut Noor Jamaluddin (1978:1) Guru adalah pendidik, yaitu orang dewasa yang bertanggung jawab memberi bimbingan atau bantuan kepada anak didik dalam perkembangan jasmani dan rohaninya agar mencapai kedewasaannya, mampu berdiri dapat melaksanakan tugasnya sebagai makhluk Allah Khalifah di muka bumi, sebagai makhluk sosial dan individu yang sanggup berdiri sendiri.

Guru adalah profesi yang merupakan suatu jabatan yang memerlukan keahlian khusus dalam hal mengajar dan tidak dapat dilakukan oleh sembarangan orang diluar bidang pendidikan. Walaupun kenyataannya masih terdapat guru yang tidak memiliki latar belakang pendidikan bidang keguruan. (Susanto, 2020: 16)

\section{PERAN GURU SEBAGAI SEBUAH PROFESI}

Profesi guru dapat diartikan sebagai suatu pekerjaan atau jabatan yang menuntut keahlian, dapat melalui pendidikan yang sudah digapai diperguruan tinggi maupun pelatihan tertentu, menurut persyaratan khusus memiliki tanggung jawab dan kode etik tertentu yang dicantumkan didalam undang-undang atau aturan yang telah dibuat agar seorang guru tetap dengan norma yang berlaku.Sedangkan Rickey (1987) sebagaimana dikutif Soetjipto dan Kosasi (2009:17) mengemukakan ciri-ciri guru sebagai profesi

1. Adanya komitmen dari para guru bahwa jabatan itu mengharuskan pengikutnya menjunjung tinggi martabat kemanusiaan lebih dari pada mencari keuntungan diri sendiri.

2. Suatu profesi mensyaratkan orangnya mengikuti persiapan profesional dalam jangka waktu tertentu.

3. Harus selalu menambah pengetahuan agar terus menerus berkembang dalam jabatannya.

4. Memiliki kode etik jabatan.

5. Memiliki kemampuan intelektual menjawab masalah-masalah yang dihadapi.

6. Selalu ingin belajar terus-menerus mengenai bidang keahlian yang ditekuni. 
7. Menjadi anggota dari suatu organisasi profesi. Jabatan itu dipandang sebagai suatu karir hidup. (Susanto, 2020: 17)

Menurut National Education Association (NEA), syarat guru sebagai profesi terpenuhi karena memiliki kriteria:

1. Jabatan yang melibatkan kegiatan intelektual.

2. Jabatan yang menggeluti suatu batang tubuh ilmu yang khusus.

3. Jabatan yang memerlukan persiapan profesional yang lama.

4. Jabatan yang melibatkan memerlukan latihan dalam jabatan yang berkesinambungan.

5. Jabatan yang menjanjikan karier hidup dalam keanggotaan yang permanen.

6. Jabatan yang menentukan baku (standar) sendiri.

7. Jabatan yang lebih mementingkan layanan di atas keuntungan pribadi.

8. Jabatan yang mempunyai organisasi profesional yang kuat dan terjalin erat.

Robert W. Rickey (Arikunto, 1990:235) mengemukakan ciri-ciri dan syarat-syarat profesi sebagai berikut:

1. Lebih mementingkan pelayanan kemanusiaan yang ideal dibandingkan dengan kepentingan pribadi.

2. Seorang pekerja profesional, secara aktif memerlukan waktu yang panjang untuk mempelajari konsep-konsep serta prinsip-prinsip pengetahuan khusus yang mendukung keahlian.

3. Memiliki kualifikasi tertentu untuk memasuki profesi tersebut serta mampu mengikuti perkembangan dalam pertumbuhan jabatan.

4. Memiliki kode etik yang mengatur keanggotaan, tingkah laku, sikap, dan cara kerja. Membutuhkan suatu kegiatan intelektual yang tinggi. (Susanto, 2020: 19)

Guru adalah profesi dibidang pendidikan. Guru dapat diartikan sebagai orang yang ditugaskan untuk mencerdaskan anak bangsa dan kehidupan bangsa dalam semua aspeknya, baik spiritual dan emosional, intelektual, fisikal dll. Guru sebagai sebuah profesi di bidang pendidikan memiliki hak dan kewajiban yang menyangkut dunia pendidikan yang geluti. Jabatan guru memiliki banyak tugas, baik yang terikat oleh dinas maupu diluar dinas dalam bentuk pengabdian. (Susanto, 2020: 37)

Jika diidentifikasi dari filosofi pendidikan Indonesia yang dicetuskan Ki Hadjar Dewantara "ing ngarso sung tulodo, ing madya mangun karso, tutwuri handayani" maka peran guru adalah sebagai:

a. Role model (ing ngarso sung tulodo), memberikan teladan kepada siswa karena fungsi guru menjadi pemimpin siswa dalam kegiatan pembelajaran. 
b. Motor penggerak (ing madya mangun karso), guru harus menjadi penggerak inovasi dalam proses pendidikan dan penggerak peradaban dengan mengarahkan siswa untuk melakukan yang benar.

c. Motivator (tutwuri handayani), mampu memberikan dorongan semangat kepada siswa untuk menghadapi setiap persoalan dan mempelajari nilai-nilai kehidupan.

(Susanto, 2020: 38)

Dalam menjalankan tugas dan profesinya, guru memiliki hak dan kewajiban yang harus dilaksanakan dan perhatikan. Dalam UU No. 14 Tahun 2005 tentang guru dan dosen pada bagian kedua mengenai hak dan kewajiban pada pasal 14, adapun hak yang dimiliki oleh seorang guru sebagai berikut:

a. Memperoleh penghasilan di atas kebutuhan hidup minimum dan jaminan kesejahteraan sosial.

b. Mendapatkan promosi dan penghargaann sesuai dengan tugas dan prestasi kerja.

c. Memperoleh perlindungan dalam melaksanakan tugas dan hak atas kekayaan intelektual.

d. Memperoleh kesempatan untuk meningkatkan kompetensi.

e. Memperoleh dan memanfaatkan sarana dan prasarana pembelajaran untuk menunjang kelancaran tugas keprofesionalan.

f. Memiliki kebebasan dalam memberikan penilaian dan ikut menentukan kelulusan, penghargaan, dan atau sanksi kepada peserta didik sesuai dengan kaidah pendidikan, Kode etik guru, dan peraturan perundang-undangan.

g. Memperoleh rasa aman dan jaminan keselamatan dalam melaksanakan tugas.

h. Memiliki kebebasan untuk berserikat dalam organisasi profesi.

i. Memiliki kesempatan untuk berperan dalam menentukan kebijakan pendidikan.

j. Memperoleh kesempatan untuk mengembangkan dan meningkatkan kualifikasi akademik dan kompetensi.

k. Memperoleh pelatihan dan mengembangkan profesi dibidangnya.

(Susanto, 2020: 44)

Dalam melaksanakan tugas keprofesionalan dalam UU No. 14 tahun 2005 tentang guru dan dosen, pada pasal 20 maka guru berkewajiban sebagai berikut:

a. Merencanakan pembelajaran, melaksanakan proses pembelajaran yang bermutu, serta menilai dan mengevaluasi hasil pembelajaran.

b. Mengembangkan dan meningkatkan kualifikasi akademik dan kompetensi secara berkelanjutan sejalan dengan perkembangan ilmu pengetahuan, teknologi dan seni.

c. Bertindak objektif dan tidak diskriminatif atas dasar pertimbangan jenis kelamin, agama, suku, ras, dan kondisi fisik tertentu, atau latar belakang keluarga, dan status sosial ekonomi peserta didik dalam pembelajaran. 
d. Menjunjung tinggi peraturan perundang-undangan, hukum dan kode etik guru, serta nilai-nilai agama dan etika.

Memelihara dan memupuk persatuan dan kesatuan bangsa. (Susanto, 2020: 47)

Sesungguhnya guru yang bertanggung jawab memiliki beberapa sifat, menurut Wens Tanlain dan kawan-kawan (1989:31) yaitu

a. Menerima dan mematuhi norma nilai-nilai kemanusian.

b. Memikul tugas mendidik dengan bebas, berani, gembira (tugas bukan menjadi beban baginya).

c. Sadar akan nilai-nilai yang berkaitan dengan perbuatannya serta akibat-akibat yang timbul (kata hati).

d. Menghargai orang lain, termasuk anak didik.

e. Bijaksana dan hati-hati (tidak nekat, tidak sembrono, tidak singkat akal).

Takwa terdapat tuhan yang maha esa. (Susanto, 2020: 50)

\section{GURU INDONESIA DAN TANTANGAN PROFESIONALISME}

Pada umumnya orang memberi arti sempit terhadap pengertian profesional. Profesional sering diartikan sebagai suatu keterampilan teknis yang dimiliki seseorang. Misalnya, seorang guru dikatakan profesional bila guru itu memiliki kualitas pembelajaran yang tinggi. Padahal profesional mengandung makna yang lebih luas dari berkualitas tinggi dalam hal teknis.

Profesionalisme guru sangatlah diperlukan untuk memajukan pendidikan di Indonesia. Orang yang profesional akan mampu merencanakan pengajaran dengan baik, karena orang yang profesional sudah memiliki pengetahuan dan ilmu khusus yang sudah dipelajari diperguruan tinggi. Guru itu memiliki kemampuan melaksanakan prosedur mengajar, bahwa guru itu mampu untuk menerapkan secara nyata rencana pengajaran yang telah dibuat pada saat pembelajaran, hal-hal yang direncanakan pada perencanaan pengajaran diwujudkan dalam bentuk tindakan pembelajaran yang nyata. Seorang pendidik mampu melaksanakan hubungan pribadi dengan siswa, seorang guru diharuskan untuk bisa memahami siswa sesuai dengan apa yang telah dipelajari di dunia perkuliahan. Sekolah dan kelas dapat dipandang sebagai suatu sistem sosial. Sebab, didalamnya terjadi interaksi atau hubungan timbal balik antara orang-orang yang ada didalamnya, yaitu: guru, dengan siswa dan siswa dengan siswa. (Susanto, 2020: 56)

Tanpa ada nya guru yang profesional maka pendidikan di Indonesia tidak akan pernah berjalan dengan baik karena tidak ada ilmu yang pas mengajarkan kepada peserta didik. Menjadi seorang guru itu haruslah menempuh pendidikan dibidang pendidikan maka dari itu akan dikatakan profesional.

Komponen kompetensi yang harus dimiliki guru untuk dapat disebut sebagai guru profesional. 


\section{Kompetensi Profesional Guru}

Kompetensi profesional merupakan kemampuan dasar yang harus dimiliki oleh guru. Ada beberapa pandangan ahli tentang kompetensi profesional guru. Menurut Cooper (1984:15) terbagi kedalam 4 komponen kompetensi dasar, yakni:

a. Mempunyai pengetahuan tentang belajar dan tingkah laku manusia.

b. Mempunyai pengetahuan dan menguasai bidang studi yang dibinanya.

c. Mempunyai sikap yang tepat tentang diri sendiri, sekolah, teman sejawat dan bidang studi yang dibinanya.

Mempunyai keterampilan dalam teknik mengajar. (Susanto, 2020: 62)

\section{Kompetensi Pedagogik Guru}

Pedagogik adalah teori mendidik yang mempersoalkan apa dan bagaimana mendidik sebaik-baiknya (Suardi, 1979:113).

Menurut Zamania (2008:28), kompetensi pedagogik adalah kemampuan seorang pendidik dalam mengelola pembelajaran peserta didik yang meliputi:

a. Kemampuan dalam memahami peserta didik.

b. Kemampuan dalam membuat perancangan pembelajaran.

c. Kemampuan melaksanakan pembelajaran yang mendidik dari dialogis.

d. Kemampuan dalam evaluasi hasil-hasil belajar.

e. Kemampuan dalam mengembangkan peserta didik untuk mengaktualisasikan berbagai potensi yang dimilikinya. (Susanto, 2020: 67)

\section{Kompetensi Sosial Guru}

Kompetensi sosial guru merupakan kemampuan guru untuk memahami dirinya sebagai bagian dari masyarakat dan mampu mengembangkan tugas sebagai anggota masyarakat dan warga negara (Satori, dkk, 2008: 215).

Menurut Jejan Musfah (2015) pengertian kompetensi sosial guru merupakan kemampuan pendidik sebagai bagian dari masyarakat untuk:

a. Berkomunikasi lisan dan tertulis, bahwa seorang guru harus menguasai kemampuan berkomunikasi dengan masyarakat, orang tua, dan peserta didik.

b. Menggunakan teknologi komunikasi dan informasi secara fungsional, bahwa guru dituntut harus bisa memanfaatkan teknologi informasi dan komunikasi sebijak mungkin sebagai media pembelajaran apalagi dizaman covid19 ini.

c. Bergaul secara efektif dengan peserta didik, sesama pendidik, tenaga kependidikan, orang tua atau wali peserta didik. Guru harus bisa menjalin pergaulan yang baik dengan peserta didik.

d. Bergaul secara santun dengan masyarakat sekitar, bahwa seorang guru harus bergaul dengan masyarakat secara santun. (Susanto, 2020: 74) 


\section{SIMPULAN}

Guru merupakan peran terpenting peradapan pendidikan di Indonesia maupun di dunia. Guru yang mengupayakan perencanaan dan melaksanakan proses pembelajaran dikelas, menilai serta membimbing peserta didik untuk menggapai impiannya. Profesi keguruan merupakan profesi yang akan menentukan masa depan anak bangsa.

Profesi dapat diartikan sebagai suatu pekerjaan atau jabatan yang menuntut keahlian, dapat melalui pendidikan yang sudah digapai diperguruan tinggi maupun pelatihan tertentu, menurut persyaratan khusus memiliki tanggung jawab dan kode etik tertentu yang dicantumkan didalam undang-undang atau aturan yang telah dibuat agar seorang guru tetap dengan norma yang berlaku.

Guru adalah profesi dibidang pendidikan. Guru dapat diartikan sebagai orang yang ditugaskan untuk mencerdaskan anak bangsa dan kehidupan bangsa dalam semua aspeknya, baik spiritual dan emosional, intelektual, fisikal dll. Guru sebagai sebuah profesi di bidang pendidikan memiliki hak dan kewajiban yang menyangkut dunia pendidikan yang geluti. Jabatan guru memiliki banyak tugas, baik yang terikat oleh dinas maupu diluar dinas dalam bentuk pengabdian.

Profesionalisme guru sangatlah diperlukan untuk memajukan pendidikan di Indonesia. Orang yang profesional akan mampu merencanakan pengajaran dengan baik, karena orang yang profesional sudah memiliki pengetahuan dan ilmu khusus yang sudah dipelajari diperguruan tinggi.

Komponen kompetensi yang harus dimiliki guru untuk dapat disebut sebagai guru profesional yaitu Kompetensi Profesional Guru, Kompetensi Pedagogik Guru, dan Kompetensi Sosial Guru.

\section{REFERENSI}

Efendi, I., Prawitasari, M., \& Susanto, H. (2021). Implementasi Penilaian Pembelajaran Pada Kurikulum 2013 Mata Pelajaran Sejarah. Prabayaksa: Journal of History Education, 1(1), 21-25.

Susanto, H. (2020). Profesi Keguruan. Banjarmasin: FKIP Universitas Lambung Mangkurat.

Susanto, H., \& Akmal, H. (2018). Efektivitas Penggunaan Aplikasi Pembelajaran Berbasis Mobile Smartphone Sebagai Media Pengenalan Sejarah Lokal Masa Revolusi Fisik Di Kalimantan Selatan Pada Siswa Sekolah Menengah Atas. HISTORIA: Jurnal Program Studi Pendidikan Sejarah, 6(2), 197-206. 
Susanto, H., Irmawati, I., Akmal, H., \& Abbas, E. W. (2021). Media Film Dokumenter Masuknya Islam Ke Nusantara dan Pengaruhnya Terhadap Keterampilan Berpikir Kritis Siswa. HISTORIA: Jurnal Program Studi Pendidikan Sejarah, 9(1).

Syaharuddin, S., \& Susanto, H. (2019). Sejarah Pendidikan Indonesia (Era Pra Kolonialisme Nusantara sampai Reformasi). Banjarmasin: FKIP Universitas Lambung Mangkurat. 